\title{
Assessment of the Radiological Consequences of a Radioactive Release under Wet Weather Conditions in a Research Reactor Accident Scenario
}

\author{
Boubker Belhaj $^{1}$, Tahar El Khoukhi ${ }^{2}$, El Mahjoub Chakir ${ }^{1}$, Hamid Boukhal $^{3} \&$ Tarek El Bardouni $^{3}$ \\ ${ }^{1}$ LHESIR, Faculty of sciences of Kenitra, Morocco \\ ${ }^{2}$ CNESTEN, PO Box 1382 R.P Rabat, Morocco \\ ${ }^{3}$ ERNS, Faculty of sciences of Tetuan, Morocco \\ Correspondence: Boubker Belhaj, LHESIR, Faculty of sciences of Kenitra, Morocco. E-mail: \\ belhaj_scti@yahoo.fr
}

Received: October 23, 2014

Accepted: October 31, $2014 \quad$ Online Published: January 16, 2015

doi:10.5539/mas.v9n3p241

URL: http://dx.doi.org/10.5539/mas.v9n3p241

\begin{abstract}
Accidental releases of radioactive substances have a major concern on rescue and emergency personal because they can cause local or widespread contamination, endangering people and environment. The magnitude of these radioactive releases depends on several factors such as the source term, weather and topography. This study aims to evaluate the impact of rainfall on the dispersion of the radioactive cloud, especially on the ground deposition, exposure to the plume and the values of the Total Effective Dose Equivalent (TEDE). It was used the Gaussian model HOTSPOT. The scenario studied is an accident in a Pool type research reactor. Several simulations were performed with different precipitation rates. The results indicate that rainfall has a more or less significant impact on the dispersion of the radioactive cloud.
\end{abstract}

Keywords: radioactive release, dosimetric consequences, atmospheric dispersion modeling, hotspot model

\section{Introduction}

The threat of nuclear or radiological accident caused a wide discussion at emergency and response personnel especially accidents that lead to the release of radioactive materials into the atmosphere. This dispersion can cause serious radiological and dosimetric consequences for the population and the environment. The magnitude of radioactive releases depends not only on the amount of the source term, but also on the weather conditions like wind and atmospheric stability. In this work we assess the impact of precipitation on the dispersion of the radioactive cloud in the emergency stage. We focus on the behavior of ground deposition, exposure to the plume and TEDE by varying the precipitation rate $(1 \mathrm{~mm} / \mathrm{h}, 5 \mathrm{~mm} / \mathrm{h}$ and $20 \mathrm{~mm} / \mathrm{h})$. The model used in this study is the Hotspot (version 2.07.2, August 31, 2011) developed by LLNL (Lawrence Livermore National Laboratory) and recommended by NARAC (National Atmospheric Release Advisory Center) (Steven, 2011).

\section{Radiological Dose}

Radiation is a form of energy that can damage a tissue. Basically the ionizing radiations affect the structure of the molecule by ionizing its constituent atoms. As a result, the cell to which the molecule belongs is damaged. If genetic material in the cell, deoxyribonucleic (DNA) is affected then the behavior of the cell is altered. These effects on tissue are proportional to the energy deposited in the tissue. The ionizing radiation is classified according to its interaction with matter.

The quantification of radiation effects on human body (dose) is based on the concept of three pyramids as proposed by International Commission of Radiological Protection (ICRP). The first is the absorbed dose, it is the energy absorbed per mass unit. The second one is the equivalent dose which indicates not only the energy absorbed but also the harmful biological effect it can produce. The use of equivalent dose becomes necessary as for the same absorbed dose; the biological effects will be different for alpha, beta and gamma radiations. The third one is called Total Effective Dose Equivalent (TEDE) which is actually the sum of the equivalent doses to the individual organs weighted to take into account their sensitivities. 


\section{Atmospheric Dispersion of Radioactive Substances}

In the event of a release of radioactive substances into the atmosphere, the dispersion occurs depending on weather conditions, resulting in contamination of the environment and the population. This dispersion also depends on several parameters such as the release conditions (release height from the ground, the leak rate), topography (soil, presence of obstacles) and the nature of the source.

In order to assess the potential consequences of such an accidental release we use the modeling of atmospheric dispersion. The three processes to take into account in this model are transport, diffusion and deposition to the ground of the radioactive substance. To determine the concentration of the radioactive cloud, it is use the following equation of advection-diffusion (Krysta, 2011):

$$
\frac{\partial \mathrm{c}}{\partial \mathrm{t}}+\underbrace{\operatorname{div}(\mathrm{uc})}_{\text {advection }}-\underbrace{\operatorname{div}(\mathrm{K} \nabla \mathrm{c})}_{\text {diffusion }}-\mathrm{ac}=\sigma
$$

Where:

$\mathbf{C}(\mathbf{x}, \mathbf{t})$ is the volumetric concentration of activity and is expressed in Bq. $\mathrm{m}^{-3}$.

$\mathbf{Q}(\mathbf{x}, \mathbf{t})$ is the source term.

$\mathbf{u}$ is the wind speed in $\mathrm{m} \cdot \mathrm{s}^{-1}$.

$\boldsymbol{\alpha}$ represents the loss process.

$\mathbf{K}$ is a matrix of turbulent diffusion.

\subsection{The Gaussian Model}

Gaussian model is used to describe the dispersion of a gas or an Aerosol assuming only the action of air as carrier fluid. Transport and diffusion of gas depend on the wind and mechanical and thermal air turbulence. It is used for modeling the dispersion of pollutants over a few hundred meters to a few kilometers. It requires meteorological data such as wind speed and direction, atmospheric stability conditions, topography type and data related to the nature and the quantity of the source dispersed.

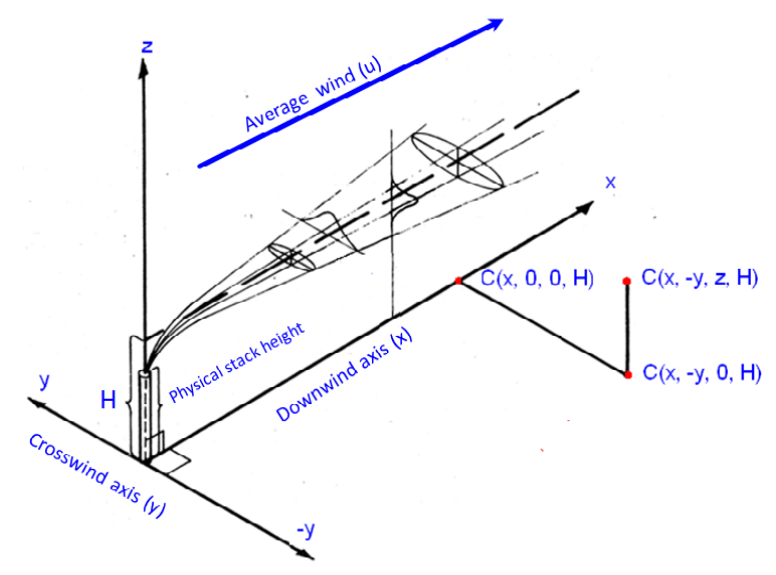

Figure 1. Gaussian dispersion scheme

\subsection{Description of the Hotspot Code}

Hotspot model provides a first order approximation of radiation effects due to the atmospheric dispersion of radioactive substances. This code was developed by LLNL (Lawrence Livermore National Laboratory) and recommended by NARAC (National atmospheric release advisory center). It's intended primarily for emergency response teams and planners to radiological and nuclear emergencies and it has capabilities of modeling several accident scenarios by displaying areas and contaminated surfaces (Steven, 2011). The code is based on a Gaussian approach to calculate the concentration by resolving the following equation:

$$
C(x, y, z, H)=\frac{Q}{2 \pi \sigma_{y} \sigma_{z} u} \exp \left[-\frac{1}{2}\left(\frac{y}{\sigma_{y}}\right)^{2}\right]\left\{\exp \left[-\frac{1}{2}\left(\frac{z-H}{\sigma_{z}}\right)^{2}\right]+\exp \left[-\frac{1}{2}\left(\frac{z+H}{\sigma_{z}}\right)^{2}\right]\right\} \exp \left[-\frac{\lambda x}{u}\right] D F(x)
$$


Where:

C is concentration $\left(\mathrm{Ci.s} / \mathrm{m}^{3}\right)$,

$\mathbf{Q}$ is source term $(\mathrm{Ci})$,

$\mathbf{H}$ is release height (m),

$\lambda$ is decay constant $\left(\mathrm{s}^{-1}\right)$,

$\mathbf{x}$ and $\mathbf{y}$ are horizontal coordinates $(\mathrm{m})$ and $\mathbf{z}$ is vertical coordinate ( $\mathrm{m}$ ),

$\boldsymbol{\sigma}(\mathbf{y}, \mathbf{z})$ is the standard deviation,

$\mathbf{u}$ is the average wind speed at the effective release height $(\mathrm{m} / \mathrm{s})$,

DF (x) is the attenuation factor of the plume (depend on $\mathrm{x}$ ).

\section{Data and Methods}

In order to assess the impact of rainfall of the radioactive cloud especially on the ground deposition, surface exposure, and the TEDE. It was performed several simulations by introducing the "rainfall" parameter in Hotspot model with different rates $(0.5 \mathrm{~mm} / \mathrm{h}, 1 \mathrm{~mm} / \mathrm{h}, 5 \mathrm{~mm} / \mathrm{h}$ and $20 \mathrm{~mm} / \mathrm{h})$. The stability class used are (A: very unstable) and (C: slightly unstable) according to Pasquill classification.

\subsection{Description of the Scenario}

The scenario describe an accident in a nuclear reactor due to heat excess accumulated in the core of a Pool type Research reactor appropriate to a power upgrade to $10 \mathrm{MW}$, following a failure in the cooling system causing the release of radioactive substances into the atmosphere.

\subsection{Initial Data}

Table 1 shows the activity inventories of important radionuclides in the reactor core at the time of accident, along with their release fractions and the activity released to the atmosphere. The total amount activity is

$1.4110^{17} \mathrm{~Bq}$. The release is produced at a level of $72 \mathrm{~m}$. The accident terrain is standard characterized by a low roughness length ( 0.01 to 0.1 meters). Other model inputs parameters are:

Damage Ratio: 1.0

Leakpath Factor: 1.0

Airborne Fraction: 0.01

Respirable Fraction: 1.0

Deposition velocity: $0.3 \mathrm{~cm} / \mathrm{s}$

Receptor Height: $1.5 \mathrm{~m}$

Inversion Layer Height: None

Breathing Rate: $4.1710^{-4} \mathrm{~m}^{3} / \mathrm{s}$

FGR-13 Dose Conversion Data - Total Effective Dose (TED)

Table 1. Radionuclide inventory in the core, release fraction and isotopic activity released to the atmosphere. (Raza, \& Iqbal, 2005)

\begin{tabular}{lllll}
\hline Nuclide & Group & Core inventory & Release fraction & Activity released \\
\hline $\mathbf{K r}-\mathbf{8 3} \mathbf{~ m}$ & Noble gas & $5.38 \mathrm{E}+14$ & 1 & $5.38 \mathrm{E}+14$ \\
$\mathbf{K r - 8 5} \mathbf{~ m}$ & Noble gas & $3.72 \mathrm{E}+15$ & 1 & $3.72 \mathrm{E}+15$ \\
$\mathbf{K r - 8 7}$ & Noble gas & $7.36 \mathrm{E}+15$ & 1 & $7.36 \mathrm{E}+15$ \\
$\mathbf{K r - 8 8}$ & Noble gas & $1.02 \mathrm{E}+16$ & 1 & $1.02 \mathrm{E}+16$ \\
$\mathbf{K r - 8 9}$ & Noble gas & $1.39 \mathrm{E}+16$ & 1 & $1.39 \mathrm{E}+16$ \\
$\mathbf{X e - 1 3 1} \mathbf{~ m}$ & Noble gas & $2.92 \mathrm{E}+15$ & 1 & $2.92 \mathrm{E}+15$ \\
$\mathbf{X e - 1 3 3}$ & Noble gas & $1.00 \mathrm{E}+16$ & 1 & $1 \mathrm{E}+16$ \\
$\mathbf{X e - 1 3 5} \mathbf{~ m}$ & Noble gas & $5.76 \mathrm{E}+15$ & 1 & $5.76 \mathrm{E}+15$ \\
$\mathbf{X e - 1 3 5}$ & Noble gas & $1.88 \mathrm{E}+16$ & 1 & $1.88 \mathrm{E}+16$ \\
$\mathbf{X e - 1 3 7}$ & Noble gas & $1.76 \mathrm{E}+16$ & 1 & $1.76 \mathrm{E}+16$ \\
$\mathbf{X e - 1 3 8}$ & Noble gas & $1.79 \mathrm{E}+16$ & 1 & $1.79 \mathrm{E}+16$ \\
\hline
\end{tabular}




\begin{tabular}{lllll}
\hline I-131 & Halogen & $3.55 \mathrm{E}+15$ & 0.4 & $1.78 \mathrm{E}+15$ \\
I-132 & Halogen & $1.24 \mathrm{E}+16$ & 0.4 & $4.96 \mathrm{E}+15$ \\
I-133 & Halogen & $1.93 \mathrm{E}+16$ & 0.4 & $7.72 \mathrm{E}+15$ \\
I-134 & Halogen & $2.24 \mathrm{E}+16$ & 0.4 & $8.96 \mathrm{E}+15$ \\
I-135 & Halogen & $1.81 \mathrm{E}+16$ & 0.4 & $7.24 \mathrm{E}+15$ \\
Sr-89 & Br-Sr group & $3.83 \mathrm{E}+16$ & 0.02 & $7.66 \mathrm{E}+14$ \\
Sr-90 & Br-Sr group & $1.77 \mathrm{E}+14$ & 0.02 & $3.54 \mathrm{E}+12$ \\
Y-91 & Lanthanide & $4.65 \mathrm{E}+15$ & 0.0002 & $9.3 \mathrm{E}+11$ \\
Zr-95 & Lanthanide & $5.08 \mathrm{E}+15$ & 0.0002 & $1.02 \mathrm{E}+12$ \\
Zr-97 & Lanthanide & $1.69 \mathrm{E}+16$ & 0.0002 & $3.38 \mathrm{E}+12$ \\
Nb-95 & Lanthanide & $5.41 \mathrm{E}+15$ & 0.0002 & $1.08 \mathrm{E}+12$ \\
Ba-140 & Br-Sr group & $6.51 \mathrm{E}+15$ & 0.02 & $1.3 \mathrm{E}+14$ \\
Ce-141 & Cerium group & $4.86 \mathrm{E}+15$ & 0.0005 & $2.43 \mathrm{E}+12$ \\
Ce-143 & Cerium group & $1.58 \mathrm{E}+16$ & 0.0005 & $7.9 \mathrm{E}+12$ \\
Ce-144 & Cerium group & $4.47 \mathrm{E}+15$ & 0.0005 & $8.94 \mathrm{E}+11$ \\
Pr-143 & Lanthanide & $6.05 \mathrm{E}+15$ & 0.0002 & $1.21 \mathrm{E}+12$ \\
Nd-147 & Lanthanide & $2.47 \mathrm{E}+15$ & 0.0002 & $6.18 \mathrm{E}+12$ \\
Ru-103 & Noble metal & $2.45 \mathrm{E}+15$ & 0.0025 & $6.13 \mathrm{E}+12$ \\
Rh-105 & Noble metal & $2.34 \mathrm{E}+15$ & 0.0025 & $5.85 \mathrm{E}+12$ \\
Ru-106 & Noble metal & $2.77 \mathrm{E}+14$ & 0.0025 & $6.93 \mathrm{E}+11$ \\
Te-127 m & Tellurium & $1.88 \mathrm{E}+14$ & 0.05 & $9.4 \mathrm{E}+12$ \\
Te-129 m & Tellurium & $8.35 \mathrm{E}+14$ & 0.05 & $4.18 \mathrm{E}+13$ \\
Te-131 m & Tellurium & $7.89 \mathrm{E}+15$ & 0.05 & $3.95 \mathrm{E}+14$ \\
Te-132 & Tellurium & $8.22 \mathrm{E}+15$ & 0.05 & $4.11 \mathrm{E}+14$ \\
$\mathbf{C s - 1 3 7}$ & Alkali metal & $1.63 \mathrm{E}+14$ & 0.3 & $\mathbf{1 . 4 1 E}+\mathbf{1 7}$ \\
\hline & & $\mathbf{3 . 1 7 E}+\mathbf{1 7}$ & $\mathbf{4 . 4 5 E} \mathbf{- 0 1}$ &
\end{tabular}

\subsection{Wind Rose Analysis}

Analysis of wind speed and direction over a period of 30 years of measurements for the accident area (Fig, 2) lead to choose the westerly direction as dominant direction and a speed of $5 \mathrm{~m} / \mathrm{s}$.

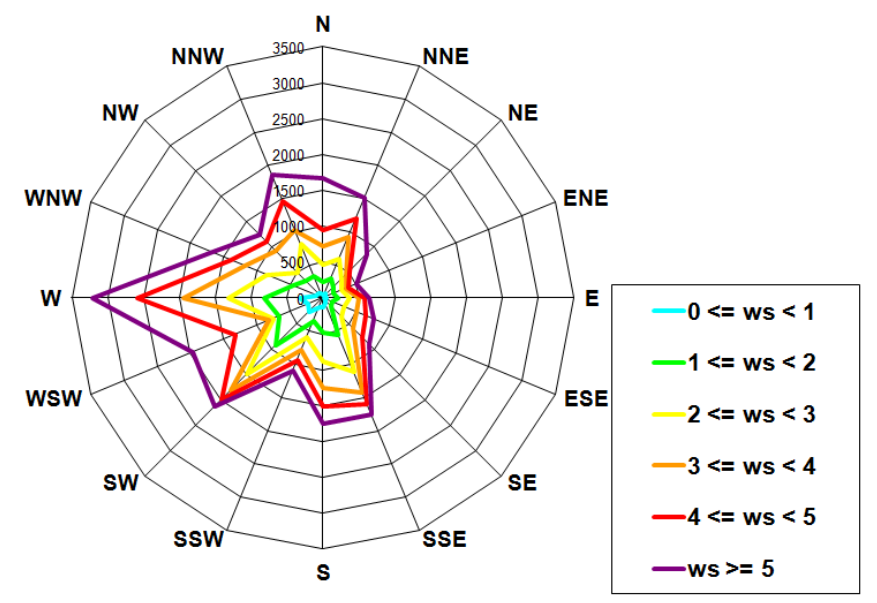

Figure 2. Wind rose at $10 \mathrm{~m}$ height for 16 directional sectors

\section{Methodology}

The actual plume height may not be the physical release height. Plume rise can occur because of the velocity of the stack efflux, and the temperature differential between the stack effluent and the surrounding air. The rise of the plume results in an increase in the release height (Steven, 2011). 


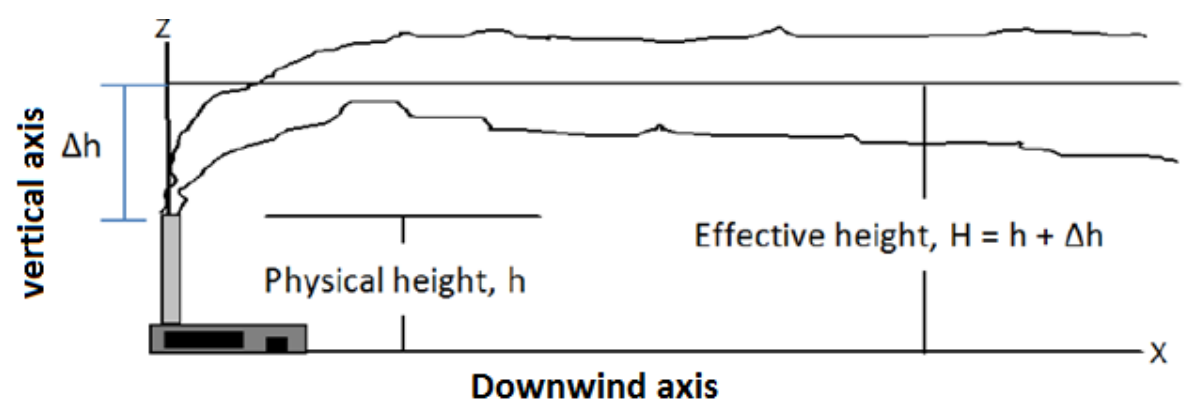

Figure 3. Physical height (h) and Plume Effective Height (H)

HotSpot calculates both the momentum plume rise and the buoyant plume rise and chooses the greater of the two results.

\subsection{Plume Rise due to Buoyancy}

The buoyancy flux, $\boldsymbol{F}$ is:

$$
F=r^{2} g v\left(1-\frac{T_{a}}{T_{s}}\right)
$$

Where:

$g=$ gravitational acceleration $\left(9.8 \mathrm{~m} / \mathrm{s}^{2}\right)$

$v=$ stack exit velocity $(\mathrm{m} / \mathrm{s})$

$r=$ stack radius (m)

$T_{a}=$ ambient air temperature $(\mathrm{K})$

$T_{s}=$ stack effluent temperature $(\mathrm{K})$

The effective release height, $\mathrm{H}$, due to buoyancy plume rise is determined as follows:

For atmospheric stability classifications A, B, C, and D, (unstable to neutral),

$$
\mathrm{H}=\mathrm{h}+\frac{1.6(\mathrm{~F})^{1 / 3}\left(\mathrm{X}^{*}\right)^{2 / 3}}{\mathrm{u}(\mathrm{h})}
$$

Where:

$\mathrm{h}=$ physical stack height $(\mathrm{m})$

$u(\mathrm{H})=$ wind speed at effective release height $(\mathrm{m} / \mathrm{s})$

$\mathrm{X}^{*}=$ distance associated with final plume height $(\mathrm{m})$

$$
\begin{aligned}
& \mathrm{X}^{*}=119 \mathrm{~F}^{0.40} \text { for } \mathrm{F} \geq 55 \\
& \mathrm{X}^{*}=49 \mathrm{~F}^{0.625} \text { for } \mathrm{F}<55
\end{aligned}
$$

For stability classifications E, F and G, (stable),

For $u(h)>1.4 \mathrm{~m} / \mathrm{s}$ :

$$
\mathrm{H}=\mathrm{h}+2.6\left(\frac{F}{u(h) S}\right)^{1 / 3}
$$

For $(h) \leq 1.4 \mathrm{~m} / \mathrm{s}$ :

$$
\mathrm{H}=\mathrm{h}+5 \mathrm{~F}^{1 / 4} \mathrm{~S}^{-3 / 8}
$$

where

$\mathrm{S}=0.020 \mathrm{~g} / \mathrm{T}_{\mathrm{a}}$ for stability class $\mathrm{E}$

$\mathrm{S}=0.035 \mathrm{~g} / \mathrm{T}_{\mathrm{a}}$ for stability class $\mathrm{F}$

\subsection{Momentum Plume Rise}

The effective release height due to momentum plume rise is determined as follows: 
For atmospheric stability classifications A, B, C and D, (unstable to neutral),

$$
\mathrm{H}=\mathrm{h}+\frac{6 \mathrm{vr}}{\mathrm{u}(\mathrm{h})}
$$

Where:

$v=$ stack exit velocity $(\mathrm{m} / \mathrm{s})$

$h=$ physical stack height $(\mathrm{m})$

$r=$ stack radius $(\mathrm{m})$

$u(h)=$ wind speed at physical stack height $(\mathrm{m} / \mathrm{s})$

For stability classifications E and F,

$$
\mathrm{H}=\mathrm{h}+1.5\left(\frac{F}{u(h)}\right)^{1 / 3} S^{-1 / 6}
$$

Where

$$
\mathrm{F}=0.25(2 \mathrm{rv}) 2
$$

$\mathrm{S}=0.000875$ for stability class $\mathrm{E}$

$\mathrm{S}=0.00175$ for stability class $\mathrm{F}$

\subsection{Wet Deposition Modeling}

The theoretical treatment of wet deposition is often divided into rainout (scavenging within the rain cloud), and washout (scavenging below the rain cloud).In many practical applications and HotSpot, the two processes are simply combined and treated as a single removal process. If the wet deposition option is enabled in HotSpot, the effects of precipitation will be modeled by exponentially decreasing the radionuclide concentration as follows.

$$
C^{\prime}(x, y, z)=C(x, y, z) \cdot \exp (-\Lambda x / u)
$$

Where:

$\mathrm{C}^{\prime}=$ concentration $(\mathrm{Bq} / \mathrm{m} 3)$

$\Lambda=$ washout coefficient $\left(\mathrm{s}^{-1}\right)$

$\mathrm{u}=$ mean wind speed $(\mathrm{m} / \mathrm{s})$.

Table 2. Typical Coefficient values

\begin{tabular}{cr}
\hline Rain rate $(\mathbf{m m} / \mathbf{h})$ & Rainout Coefficient \\
\hline 0.5 & 0.0001 \\
1 & 0.0002 \\
5 & 0.0006 \\
10 & 0.0010 \\
15 & 0.0013 \\
20 & 0.0017 \\
25 & 0.0020 \\
\hline
\end{tabular}

\section{Results and Discussion}

Results show that the presence of a rainfall $(5 \mathrm{~mm} / \mathrm{h}$ to $20 \mathrm{~mm} / \mathrm{h})$ in a slightly unstable atmosphere and an average wind speed of $5 \mathrm{~m} / \mathrm{s}$, the surface of the ground deposition is less wide than the case without rain. This change in surface is less significant in case of a light rain. (Figure 4 (a) and (b))

However, in case of a very unstable situation with an average wind speed, the light rain impact is more significant, indeed, the surface of the ground deposition increased with a factor of 10 for of $1 \mathrm{~mm} / \mathrm{h}$ of rain in comparison with dry weather. But this surface slightly decreased in case of a heavy rain $(25 \mathrm{~mm} / \mathrm{h})$ under the same wind and stability conditions. (Figure 4 (c) and (d))

Results shows also that the impact of rain on the plume and TEDE and TEDE max values is non significant under slightly or very unstable conditions. (figure 4 (e) and (f)) and (table 3 and 4 ). 
a)

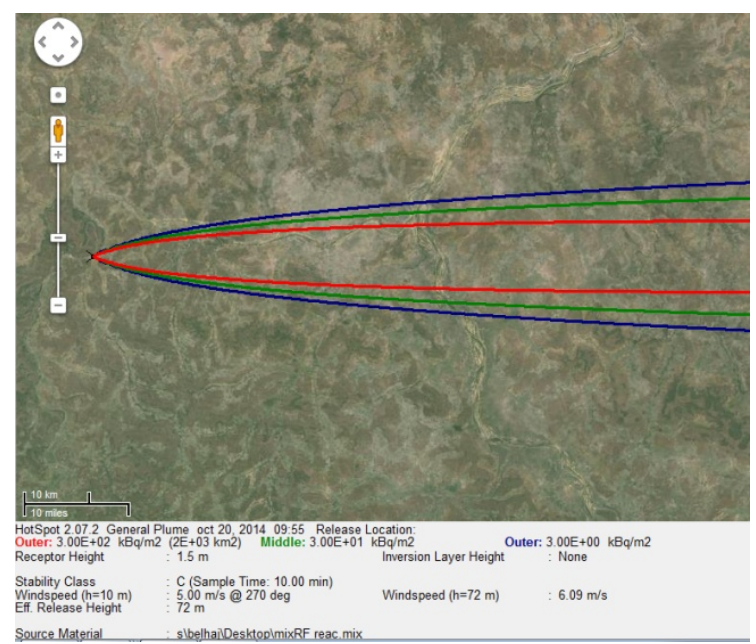

c)

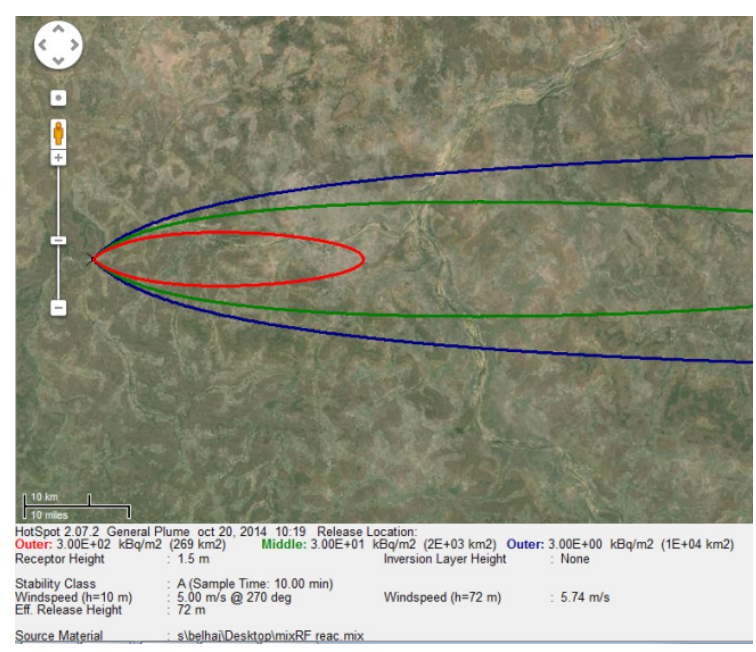

e)

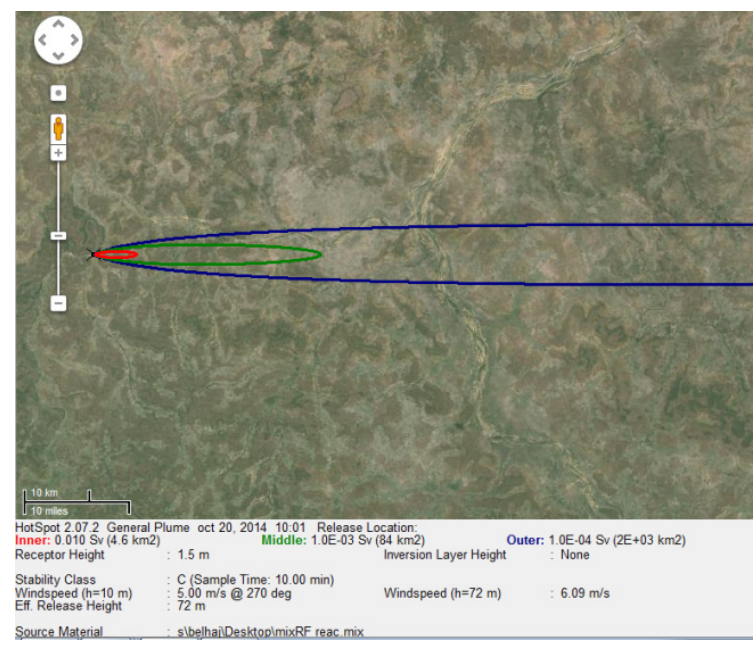

b)

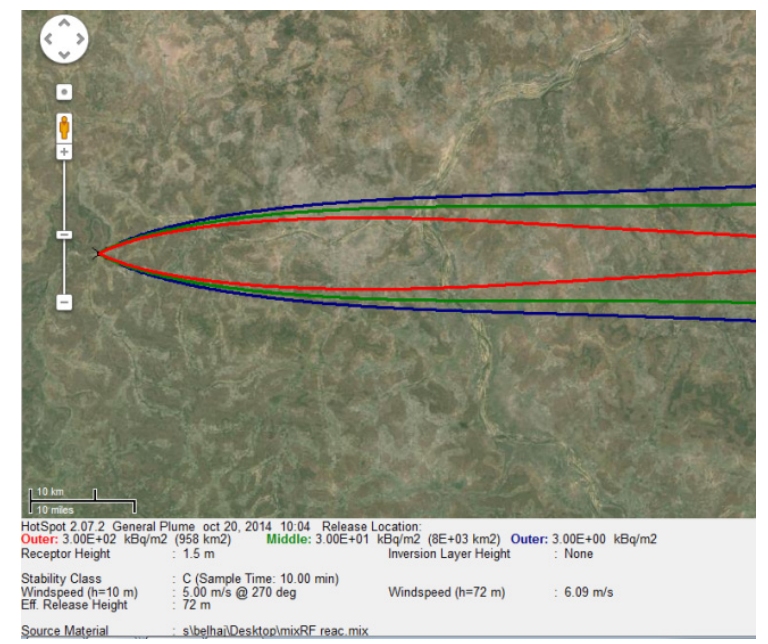

d)

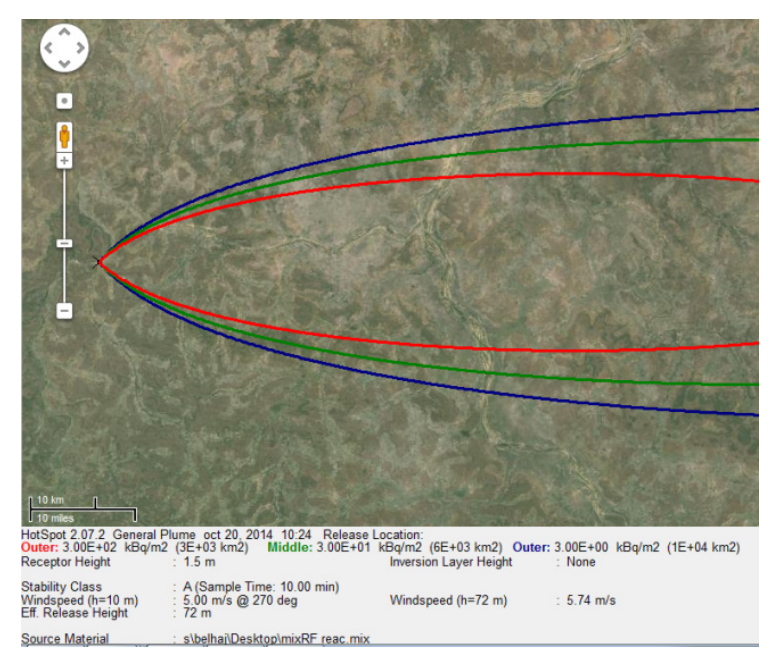

f)

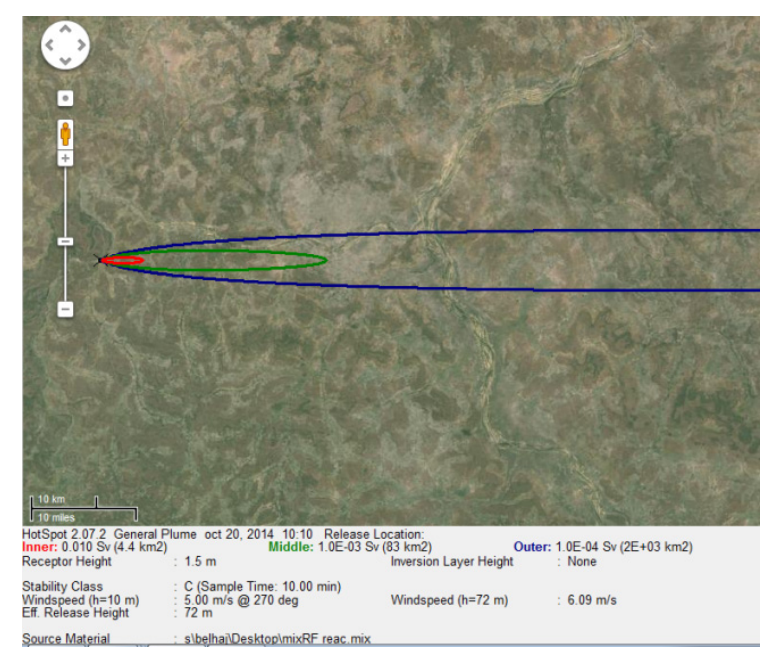

Figure 4. Ground deposition surface under dry weather (a) and (c). Under wet weather $(5 \mathrm{~mm} / \mathrm{h})(\mathrm{b}),(1 \mathrm{~mm} / \mathrm{h})$ (d) $(1 \mathrm{~mm} / \mathrm{h})(e)$, exposure to the plume Under wet weather $(1 \mathrm{~mm} / \mathrm{h})$ ( e ) et $(20 \mathrm{~mm} / \mathrm{h})$ (f) derived from Hotspot model for reactor accident 
Table 3. TEDE (Sv) as a function of the distances from the release point for Pasquill stability classes (C and A) with $5 \mathrm{~m} / \mathrm{s}$ wind speed in standard terrain

\begin{tabular}{|c|c|c|c|c|c|c|c|c|}
\hline \multirow{3}{*}{$\begin{array}{r}\text { distance } \\
(\mathrm{km})\end{array}$} & \multirow[b]{3}{*}{ Dry weather } & \multirow[b]{3}{*}{$1 \mathrm{~mm} / \mathrm{h}$} & \multirow{2}{*}{\multicolumn{2}{|c|}{ stability class $\mathrm{C}$}} & \multicolumn{4}{|c|}{ Total Effective Dose Equivalent (TEDE) in Sv } \\
\hline & & & & & & & stabil & ity class $\mathrm{A}$ \\
\hline & & & $5 \mathrm{~mm} / \mathrm{h}$ & $20 \mathrm{~mm} / \mathrm{h}$ & Dry weather & $1 \mathrm{~mm} / \mathrm{h}$ & $5 \mathrm{~mm} / \mathrm{h}$ & $20 \mathrm{~mm} / \mathrm{h}$ \\
\hline 0.1 & $8.30 \mathrm{E}-17$ & $8.30 \mathrm{E}-17$ & $8.30 \mathrm{E}-17$ & $8.30 \mathrm{E}-17$ & $8.50 \mathrm{E}-03$ & $8.50 \mathrm{E}-03$ & $8.50 \mathrm{E}-03$ & $8.50 \mathrm{E}-03$ \\
\hline 0.2 & $1.90 \mathrm{E}-04$ & $1.90 \mathrm{E}-04$ & $1.90 \mathrm{E}-04$ & $1.90 \mathrm{E}-04$ & 2.70E-01 & $2.70 \mathrm{E}-01$ & $2.70 \mathrm{E}-01$ & 2.70E-01 \\
\hline 0.3 & $2.50 \mathrm{E}-02$ & $2.50 \mathrm{E}-02$ & $2.50 \mathrm{E}-02$ & $2.50 \mathrm{E}-02$ & $2.90 \mathrm{E}-01$ & $2.90 \mathrm{E}-01$ & $2.90 \mathrm{E}-01$ & $2.90 \mathrm{E}-01$ \\
\hline 0.4 & $1.10 \mathrm{E}-01$ & $1.10 \mathrm{E}-01$ & $1.10 \mathrm{E}-01$ & $1.10 \mathrm{E}-01$ & $2.30 \mathrm{E}-01$ & $2.30 \mathrm{E}-01$ & $2.20 \mathrm{E}-01$ & $2.20 \mathrm{E}-01$ \\
\hline 0.5 & $1.80 \mathrm{E}-01$ & $1.80 \mathrm{E}-01$ & $1.80 \mathrm{E}-01$ & $1.80 \mathrm{E}-01$ & $1.70 \mathrm{E}-01$ & $1.70 \mathrm{E}-01$ & $1.70 \mathrm{E}-01$ & $1.70 \mathrm{E}-01$ \\
\hline 0.6 & $2.10 \mathrm{E}-01$ & $2.10 \mathrm{E}-01$ & $2.10 \mathrm{E}-01$ & $2.10 \mathrm{E}-01$ & $1.30 \mathrm{E}-01$ & $1.30 \mathrm{E}-01$ & $1.30 \mathrm{E}-01$ & $1.20 \mathrm{E}-01$ \\
\hline 0.7 & $2.20 \mathrm{E}-01$ & $2.20 \mathrm{E}-01$ & $2.20 \mathrm{E}-01$ & $2.10 \mathrm{E}-01$ & $9.70 \mathrm{E}-02$ & $9.70 \mathrm{E}-02$ & $9.70 \mathrm{E}-02$ & $9.60 \mathrm{E}-02$ \\
\hline 0.8 & $2.10 \mathrm{E}-01$ & $2.10 \mathrm{E}-01$ & $2.10 \mathrm{E}-01$ & $2.00 \mathrm{E}-01$ & 7.70E-02 & $7.70 \mathrm{E}-02$ & 7.60E-02 & $7.60 \mathrm{E}-02$ \\
\hline 0.9 & $1.90 \mathrm{E}-01$ & $1.90 \mathrm{E}-01$ & $1.90 \mathrm{E}-01$ & $1.90 \mathrm{E}-01$ & $6.20 \mathrm{E}-02$ & $6.20 \mathrm{E}-02$ & $6.20 \mathrm{E}-02$ & $6.10 \mathrm{E}-02$ \\
\hline 1 & $1.70 \mathrm{E}-01$ & $1.70 \mathrm{E}-01$ & $1.70 \mathrm{E}-01$ & $1.70 \mathrm{E}-01$ & $5.10 \mathrm{E}-02$ & $5.10 \mathrm{E}-02$ & $5.10 \mathrm{E}-02$ & $5.00 \mathrm{E}-02$ \\
\hline 2 & $6.80 \mathrm{E}-02$ & $6.80 \mathrm{E}-02$ & $6.70 \mathrm{E}-02$ & $6.60 \mathrm{E}-02$ & $1.40 \mathrm{E}-02$ & $1.40 \mathrm{E}-02$ & $1.40 \mathrm{E}-02$ & $1.30 \mathrm{E}-02$ \\
\hline 3 & $3.60 \mathrm{E}-02$ & $3.50 \mathrm{E}-02$ & $3.50 \mathrm{E}-02$ & $3.40 \mathrm{E}-02$ & $6.40 \mathrm{E}-03$ & $6.30 \mathrm{E}-03$ & $6.30 \mathrm{E}-03$ & $6.20 \mathrm{E}-03$ \\
\hline 4 & $2.20 \mathrm{E}-02$ & $2.20 \mathrm{E}-02$ & $2.20 \mathrm{E}-02$ & $2.20 \mathrm{E}-02$ & $3.70 \mathrm{E}-03$ & $3.70 \mathrm{E}-03$ & $3.60 \mathrm{E}-03$ & $3.60 \mathrm{E}-03$ \\
\hline 5 & $1.60 \mathrm{E}-02$ & $1.60 \mathrm{E}-02$ & $1.50 \mathrm{E}-02$ & $1.50 \mathrm{E}-02$ & $2.40 \mathrm{E}-03$ & $2.40 \mathrm{E}-03$ & $2.40 \mathrm{E}-03$ & $2.30 \mathrm{E}-03$ \\
\hline 6 & $1.20 \mathrm{E}-02$ & $1.20 \mathrm{E}-02$ & $1.20 \mathrm{E}-02$ & $1.10 \mathrm{E}-02$ & $1.70 \mathrm{E}-03$ & $1.70 \mathrm{E}-03$ & $1.70 \mathrm{E}-03$ & $1.70 \mathrm{E}-03$ \\
\hline 7 & $9.40 \mathrm{E}-03$ & $9.30 \mathrm{E}-03$ & $9.10 \mathrm{E}-03$ & $9.00 \mathrm{E}-03$ & $1.30 \mathrm{E}-03$ & $1.30 \mathrm{E}-03$ & $1.30 \mathrm{E}-03$ & $1.30 \mathrm{E}-03$ \\
\hline 8 & $7.70 \mathrm{E}-03$ & $7.60 \mathrm{E}-03$ & $7.50 \mathrm{E}-03$ & $7.40 \mathrm{E}-03$ & $1.00 \mathrm{E}-03$ & $1.00 \mathrm{E}-03$ & $1.00 \mathrm{E}-03$ & $9.90 \mathrm{E}-04$ \\
\hline 9 & $6.40 \mathrm{E}-03$ & $6.40 \mathrm{E}-03$ & $6.30 \mathrm{E}-03$ & $6.20 \mathrm{E}-03$ & 8.30E-04 & $8.20 \mathrm{E}-04$ & $8.10 \mathrm{E}-04$ & $8.00 \mathrm{E}-04$ \\
\hline 10 & $5.50 \mathrm{E}-03$ & $5.50 \mathrm{E}-03$ & $5.40 \mathrm{E}-03$ & $5.30 \mathrm{E}-03$ & $6.90 \mathrm{E}-04$ & $6.80 \mathrm{E}-04$ & $6.70 \mathrm{E}-04$ & $6.60 \mathrm{E}-04$ \\
\hline 11 & $4.80 \mathrm{E}-03$ & $4.80 \mathrm{E}-03$ & $4.70 \mathrm{E}-03$ & $4.60 \mathrm{E}-03$ & $5.80 \mathrm{E}-04$ & $5.70 \mathrm{E}-04$ & $5.70 \mathrm{E}-04$ & $5.60 \mathrm{E}-04$ \\
\hline
\end{tabular}

Table 4. Max of TEDE for A and C stability class under different rain rate

\begin{tabular}{|c|c|c|c|c|c|c|}
\hline & \multicolumn{5}{|c|}{ TEDE max en Sv } & \multirow[t]{2}{*}{ Distance of max TEDE $(\mathrm{km})$} \\
\hline Stability Class $\backslash$ rain rate & Dry & $1 \mathrm{~mm} / \mathrm{h}$ & $5 \mathrm{~mm} / \mathrm{h}$ & $10 \mathrm{~mm} / \mathrm{h}$ & $20 \mathrm{~mm} / \mathrm{h}$ & \\
\hline $\mathbf{A}$ & 0.306 & 0.306 & 0.305 & 0.305 & 0.304 & $0.25 \mathrm{~km}$ \\
\hline $\mathbf{C}$ & 0.219 & 0.218 & 0.218 & 0.217 & 0.216 & $0.67 \mathrm{~km}$ \\
\hline
\end{tabular}

\section{Conclusion}

In this paper, It was studied an accident scenario causing a dispersion of radioactive substances into the atmosphere following an accident in research reactor. It was studied the impact of precipitation on the dispersion of radioactive cloud, found that rain have more or less influence on ground deposition depending on the stability class. Indeed a low rate of precipitation can largely increase the ground deposition surface, but a high rate decreases it. Likewise the impact on the exposure to the plume and TEDE is non significant.

The results of this study could be useful to emergency response personnel to quantify the dosimetric impact on people and the environment and provide adequate protective measures. However, the Gaussian model limitations should be considered given the complexity of the phenomenon of dispersion.

\section{References}

Belhaj, B., Elkhoukhi, T., Chakir, M., Boukhal, H., \& Elbardouni, T. (2013). Study of the effect of weather, topography and radionuclide on the TEDE in a fire scenario involving a dispersion of a plume in the atmosphere. Middle-East Journal of Scientific Research, 18, 1192-1198.

Drews, M. (2005). Data assimilation on atmospheric dispersion of radioactive materials. Thesis, Technical University of Denmark and Risø National Laboratory, Danemark.

Hanna, S., Briggs, R., \& Britter, R. E. (2002). Wind Flow and Vapor Cloud Dispersion at Industrial and Urban Sites. ISBN N0 0-8169-0863-X, CCPS/AIChE. 3 Park Ave., New York, NY.

Homann, S. G. (2011). National Atmospheric Release Advisory Center (NARAC) Health Physics Codes, Version 2.07.2 User's Guide.

ICRP - International Commission on Radiological Protection. (1991). Recommendations of the International 
Commission on Radiological Protection, ICRP 60. Annals of ICRP, 21, 1-3.

Jilani, A. (2009). Atmospheric Dispersion and Consequence Modeling of Radiological Emergencies, thesis, Institute of Engineering \& Applied Sciences.

Krysta, M. (2011). Modélisation numérique et assimilation de données de la dispersion de radionucléides en champ proche et à l'échelle continentale, thesis Paris XII University.

Raza, S., \& Iqbal, M. (2005). Atmospheric dispersion modeling for an accidental release from the Pakistan Research Reactor-1 (PARR-1). Annals of Nuclear Energy, 32, 1157-1166. http://dx.doi.org/10.1016/j.anucene.2005.03.008

Vogt, P., Pognaz, B., Aluzzi, F. J., Baskett, R. L., \& Sullivan, T. J. (1998). ARAC Simulation of the Algeciras, Spain Steel Mill 137Cs Release. Rapport technique JC-131330, Lawrence Livermore National Laboratory, Etats-Unis.

\section{Copyrights}

Copyright for this article is retained by the author(s), with first publication rights granted to the journal.

This is an open-access article distributed under the terms and conditions of the Creative Commons Attribution license (http://creativecommons.org/licenses/by/3.0/). 